\title{
Rodzice a nowomedialne wspomaganie współczesnej polskiej szkoły (raport z badań)
}

\begin{abstract}
Anna Michniuk, Rodzice a nowomedialne wspomaganie wspótczesnej polskiej szkoty (raport $z$ badań) [Parents and new media in modern Polish schools]. Interdyscyplinarne Konteksty Pedagogiki Specjalnej, nr 23, Poznań 2018. Pp. 249-266. Adam Mickiewicz University Press. ISSN 2300-391X. DOI: https://doi.org/10.14746/ ikps.2018.23.15

The article presents some of the conclusions of the research carried out in 2016 among the junior high schools located in lubuskie voiewodship. One of the subjects of the research was the parents of new media support for modern school assess. The text presents parents' opinions on the new media activity of students, support of new media in the teaching - learning process, building contact between the school and parents and also (auto)promotion of the school. The article also contains a short description of the new media activity of parents of contemporary teenagers and characteristic of the media world in which modern parents were brought up.
\end{abstract}

KEY WORDS: school, new media, parents

\section{Wstęp}

Rodzice współczesnych nastolatków to osoby, którym świat mediów nie jest całkowicie obcy. Często w ramach wykonywanej przez siebie pracy musieli oni poznać pewne narzędzia oraz pro- 
gramy czy aplikacje, by prawidłowo wykonywać swoje obowiązki. Duża grupa jest również aktywna w przestrzeniach wirtualnych społeczności. W artykule zostanie podjęta próba przedstawienia sylwetki rodzica współczesnego nastolatka, jego medialne dzieciństwo, a przede wszystkim jego opinie i postawy związane z nowomedialnym wspomaganiem współczesnej szkoły.

\section{Nowomedialna aktywność rodziców współczesnych nastolatków}

Podejmując próbę opisu współczesnego rodzica, warto przytoczyć wyniki badań przeprowadzonych przez TNS na zlecenie Orange Polska1, w których wzięło udział 500 dzieci oraz 702 rodziców (z których 501 korzystało z internetu, 201 nie), rodzice (w celach niezwiązanych z pracą) korzystają z internetu mniej niż ich dzieci. Większość badanych (65\%) deklaruje, że w sieci spędza mniej niż godzinę dziennie. 31\% badanych rodziców posiadało konto na portalu społecznościowym Facebook, natomiast o 10\% więcej na portalu Nasza Klasa. Badanych rodziców zapytano również o to, czy wspólnie z dziećmi spędzają czas w internecie. Jak wskazują dane, $5 \%$ rodziców zawsze towarzyszy dziecku w tego typu aktywności, natomiast $95 \%$ rodziców deklaruje, że zdarza im się to okazjonalnie. Zarówno rodzice, jak i dzieci deklarują, że najczęściej wspólnie spędzają czas w internecie na szukaniu materiałów potrzebnych do szkoły - takiej odpowiedzi udzieliło 55\% dzieci oraz 89\% dorosłych. Na kolejnych pozycjach znalazło się: oglądanie filmów (dzieci - 54\%, rodzice - 43\%), przeglądanie stron internetowych (dzieci - 52\%, rodzice - 60\%), kontaktowanie się z rodziną (dzieci $-37 \%$, rodzice $-56 \%$ ), granie $w$ gry (dzieci $-31 \%$, rodzice $38 \%$ ) oraz szukanie informacji na temat hobby (dzieci - $13 \%$, rodzi-

1 TNS na zlecenie Orange Polska, Bezpieczeństwo dzieci w internecie. Raport z badań jakościowych i ilościowych, https://panoptykon.org/files/bezpieczenstwo_ dzieci_w_internecie_2013.pdf [dostęp: 10.08.2018]. 
ce - 55\%). Na ostatnim miejscu znalazła się odpowiedź „rodzice tylko patrzą". Udzieliło jej 6\% dzieci oraz 18\% rodziców. Badanie pokazało również, że aż $66 \%$ badanych dzieci zadeklarowało, że zdarza im się pomagać rodzicom $\mathrm{w}$ znalezieniu $\mathrm{w}$ internecie pożądanych treści. Wynik ten jest jednak niezgodny z deklaracjami rodziców. Niecała połowa (dokładnie 47\%) przyznała, że ich umiejętności w zakresie obsługi komputera są nieco gorsze lub zdecydowanie gorsze od umiejętności jakie posiadają ich dzieci.

Interesujące dane przedstawia również raport GUS Społeczeństwo informacyjne w Polsce 2012-2016² w którym czytamy, że prawie $83 \%$ osób w wieku 35-44 i 63\% w wieku 45-543 korzysta z internetu, $84 \%$ i $63 \%$ robi to regularnie. Prawie dwa razy więcej osób korzysta z internetu w domu niż w pracy, tj. 87\% osób w wieku 35-44 oraz prawie $68 \%$ osób w wieku 45-54 korzysta z internetu w domu, natomiast w pracy robi to odpowiednio prawie $40 \%$ oraz prawie $29 \%$. Jeśli chodzi o sposób korzystania z internetu, niecałe $20 \%$ osób w wieku 35-44 lat korzystało z komunikatorów internetowych. W przypadku starszej grupy wynik procentowy wynosi niecałe $10 \%$. 54\% osób w wieku 35-44 lat i 33\% osób w wieku 45-54 w ciągu 12 miesięcy poprzedzających badanie zamówiło lub kupiło towary lub usługi do użytku prywatnego przez internet. Należy również dodać, że 34\% z młodszej opisywanej grupy wiekowej korzysta $\mathrm{z}$ urządzeń mobilnych w celu łącznia się z internetem, natomiast jeśli chodzi o starszą grupę, wynik wynosi 17\%. Jak pokazuje raport, najpopularniejszym urządzeniem mobilnym używanym do łączenia się z internetem jest telefon komórkowy. Korzysta z niego prawie $33 \%$ osób w wieku 35-44 lat oraz 16\% osób w wieku 45-54 lata.

Ten sam raport mówi również o poziomie cyfrowych umiejętności: informacyjnych, komunikacyjnych oraz rozwiązywania problemów. Co cieszy, prawie co drugi Polak w wieku 45-54 lat (49,6\%)

2 GUS, Społeczeństwo informacyjne w Polsce 2012-2016, https://stat.gov.pl/files/ gfx/portalinformacyjny/pl/defaultaktualnosci/5497/1/10/1/spoleczenstwo_infor macyjne_w_polsce_2012-2016.pdf [dostęp: 10.08.2018].

${ }^{3}$ Do analiz zostały wybrane te dwie grupy wiekowe dorosłych ponieważ średni wiek rodziców współczesnych nastolatków waha się od 41 do 45 lat. 
i prawie 70\% osób w wieku między 35-44 lat posiada ponadpodstawowe umiejętności informacyjne. Ponadpodstawowe umiejętności informacyjne mają osoby, które w ciągu trzech miesięcy poprzedzających badanie wykonywały kilka z wymienionych czynności: kopiowanie lub przenoszenie pliku lub folderu; korzystanie z przestrzeni dyskowej w Internecie do zapisywania dokumentów, obrazów, plików muzycznych, plików wideo lub innych plików; korzystanie z internetu do kontaktów z jednostkami administracji publicznej poprzez wyszukiwanie informacji na stronach internetowych tych jednostek; wyszukiwanie w internecie informacji o towarach lub usługach; wyszukiwanie $w$ internecie informacji związanych ze zdrowiem (np. o urazach, chorobach, odżywianiu, poprawie zdrowia itp.).

Jeśli chodzi o cyfrowe umiejętności komunikacyjne, należy zauważyć, że rodzice współczesnych nastolatków charakteryzują się nieco niższym ich poziomem. Niecałe 33\% dorosłych w wieku 45-54 lat oraz 53\% dorosłych w wieku 35-44 lat posiada ponadpodstawowe umiejętności komunikacyjne. Przez ponadpodstawowe umiejętności komunikacyjne, w niniejszym raporcie rozumie się wykonywanie co najmniej kilku ze wskazanych czynności w ciągu trzech miesięcy poprzedzających badanie: wysyłanie, odbieranie poczty elektronicznej; korzystanie z serwisów społecznościowych (tworzenie profilu użytkownika, wysyłanie wiadomości do znajomych lub inne formy uczestnictwa w takich serwisach, jak np. Facebook, Twitter, Nasza klasa, Grono itp.; telefonowanie przez internet i/lub korzystanie z kamery internetowej do wideorozmów przez internet (np. poprzez Skype lub Facetime); umieszczanie na stronie internetowej stworzonych przez siebie tekstów, zdjęć, muzyki, filmów, oprogramowania itp.

Współcześni rodzice zarówno z młodszej, jak i starszej z analizowanych grup podobnie wypadają również pod względem posiadanych umiejętności cyfrowych związanych z rozwiązywaniem problemów. W tym przypadku większość osób (tj. 50\% osób w wieku 35-44 lat oraz 29,7\% osób w wieku 45-54 lat) cechuje się ponadpodstawowym poziomem umiejętności, co oznacza, że osoby te ko- 
rzystały z internetu w ciągu ostatnich trzech miesięcy i wykonywały co najmniej jedną z czynności spośród list wskazanych w badaniu jako lista A zawierająca: przenoszenie plików pomiędzy komputerami lub innymi urządzeniami (np. aparatem fotograficznym, kamerą, telefonem komórkowym lub odtwarzaczem mp3/mp4); instalowanie oprogramowania lub aplikacji; zmienianie ustawień (opcji/preferencji w menu „narzędzia”) dowolnego oprogramowania, programu operacyjnego lub programów zapewniających bezpieczeństwo urządzenia (np. antywirusowych), oraz jako lista B, tj.: kupowanie przez internet towarów lub usług przeznaczonych do użytku prywatnego w ciągu ostatniego roku; sprzedawanie towarów lub usług przez internet, np. przez aukcje internetowe (np. Allegro, eBay); uczestniczenie w kursie online lub korzystanie przez internet $\mathrm{z}$ materiałów szkoleniowych innych niż pełny kurs online (np. materiały audiowizualne, oprogramowanie do nauki przez internet, podręczniki elektroniczne) lub kontaktowanie się z instruktorem/nauczycielem lub innymi osobami uczącymi się poprzez strony/portale edukacyjne; korzystanie z bankowości internetowej.

Zdecydowanie gorzej współcześni rodzice, zarówno w młodszej, jak i starszej analizowanej grupie, wypadają pod względem umiejętności związanych z oprogramowaniem. Ponadpodstawowe umiejętności w tym zakresie posiada niecałe $29 \%$ osób w wieku 35-44 lat oraz niecałe 18\% osób w wieku 25-34 lat. Osób nieposiadających jednak żadnych umiejętności związanych z oprogramowaniem jest więcej. W grupie 35-44 jest to prawie 35\% osób, natomiast w grupie 44-45 lat 33,5\%. Należy dodać, że w analizowanym raporcie nieposiadanie żadnych umiejętności związanych z oprogramowaniem opisywane jest jako posiadanie doświadczenia w korzystaniu $\mathrm{z}$ internetu $\mathrm{i}$ jednocześnie $\mathrm{w}$ ciągu trzech miesięcy poprzedzających badanie i jednocześnie niewykonywanie czynności z listy A (korzystanie z procesorów tekstu np. Word, Writer, WordPerfect; korzystanie z arkuszy kalkulacyjnych, np. Excel; korzystanie z oprogramowania do edytowania zdjęć, plików wideo lub audio) i B (tworzenie prezentacji lub dokumentów łączących tekst, obrazki, tabelki lub 
wykresy; tworzenie kodu w języku programowania; korzystanie $\mathrm{z}$ zaawansowanych funkcji arkusza kalkulacyjnego w celu organizacji i analizy danych, jak np. sortowanie, filtrowanie, wykorzystywanie formuł, tworzenie wykresów). Dla porównania, osoby cechujące się ponadpodstawowymi umiejętnościami związanymi z oprogramowaniem $\mathrm{w}$ ciągu trzech miesięcy korzystały $\mathrm{z}$ internetu i wykonywały co najmniej jedną czynność $\mathrm{z}$ listy $\mathrm{B}$.

Jak wynika z przedstawionych wyżej danych, rodzice współczesnych gimnazjalistów korzystają z nowych mediów, w tym również z mediów mobilnych, choć takich osób jest mniej. Internet i nowoczesne technologie nie są im obce - rodzice chętnie robią zakupy przez internet, czytają prasę czy słuchają muzyki. Oczywiście wśród młodszej grupy wyniki procentowe są wyższe, co jest w sposób oczywisty związane z roku na rok rosnącą dostępnością i popularnością nowych mediów wśród społeczeństwa. Problem stanowi twórcze korzystanie $\mathrm{z}$ nowych mediów, związane $\mathrm{z}$ tworzeniem prezentacji multimedialnych oraz szeroko rozumianych multimediów.

\section{Medialne dzieciństwo rodzica współczesnego nastolatka}

Rodzice współczesnych nastolatków to osoby w wieku ok. 41-45 lat. Chcąc więc przyjrzeć się dzieciństwu tychże osób i ich styczności z mediami na szkolnych etapach życia, należy cofnąć się do drugiej połowy $X X$ w. Osoby te urodziły się $w$ latach 70., nazywa się je dziećmi PRL-u. W tamtych czasach zdecydowanie najpopularniejszymi środkami przekazu było radio, telewizja oraz prasa. Wśród czasopism przeznaczonych dla młodzieży można wymienić „Filipinkę", a także: „Razem”, „Na przełaj”, „Świat Młodych” czy "Jestem"4.

${ }^{4}$ W. Olejniczak-Szukała, Obraz polskiej młodzieży lat osiemdziesiątych w świetle prasy młodzieżowej. Praca doktorska przygotowana pod kierunkiem prof. UAM dr hab. Doroty Skotarczak. Uniwersytet im. Adama Mickiewicza w Poznaniu, Wydział Historyczny, 2012, https:/ / repozytorium.amu.edu.pl/bitstream/10593/4490/1/doktorat2.pdf [dostęp: 6.06.2018]. 
W przypadku radia, ulubionym nadawcą młodzieży był Program 3 Polskiego Radia, czyli Trójka. Ta stacja radiowa zajmowała się głównie kulturą. Innych nadawców nie było ${ }^{5}$.

Jeśli chodzi o treści audiowizualne - tych było znacznie więcej. W programie pierwszym Telewizji Polskiej od poniedziałku do piątku w godzinach porannych nadawany był specjalny program dla szkół. $\mathrm{W}$ programie telewizyjnym wydawanym $\mathrm{w}$ formie drukowanej można było sprawdzić, jaka produkcja będzie emitowana. Nadawca podawał nazwę przedmiotu, poziom, dla którego przeznaczony był program oraz jego tytuł. Przykładowy fragment telewizyjnej ramówki zamieszczono poniżej (patrz: rys. 1). Można dowiedzieć się $\mathrm{z}$ niego, że w pewną środę telewizja o godzinie 10.55 nadawała program historyczny dotyczący egipskich faraonów dla klas piątych, a w piątek o 9.55 program dla klas licealnych, którego celem było przybliżenie młodym widzom nowoczesnych zakładów pracy.

Lata 80., jak podaje Joanna Sosnowska ${ }^{6}$, to złote lata polskich programów dziecięcych. W tym okresie powstało ich najwięcej, a niektóre z nich emitowane są nawet współcześnie (np. Ziarno). To właśnie $\mathrm{w}$ tym okresie nadawca telewizyjny odkrył, jak ciekawą formą edukowania młodzieży może być piosenka, a także magazyn z treściami przeznaczonymi dla młodego widza. 5-10-15, Pan Tik-Tak czy Domowe przedszkole to flagowe programy z tamtych czasów przeznaczone dla młodszych dzieci. Z myślą o młodzieży nadawano m.in. magazyn naukowy Kwant czy program publicystyczno-muzyczny LUZ - Ludzie Uwaga Zaczynamy.

Jak $\mathrm{w}$ takiej sytuacji odnajdywali się młodzi ludzie? Nauczyciel nie był już dla nich jedynym źródłem wiedzy. Wiele informacji do dzieci i młodzieży docierało $\mathrm{z}$ telewizji. Telewizja prezentowała różne treści, często $\mathrm{w}$ atrakcyjniejszy sposób niż nauczyciele, bowiem używała do tego ciekawych filmów, muzyki czy inspirują-

${ }^{5}$ E. Korulska, Stokowska, A. Historia radia, http://www.ceo.org.pl/sites/de fault/files/news-files/historia_radia_1.pdf [dostęp: 7.06.2018].

${ }^{6} \mathrm{~J}$. Sosnowska, Polskie telewizyjne programy edukacyjne dla dzieci i młodzieży - zarys historyczny, [w:] Media w edukacji: wymiar kulturowy i aksjologiczny, red. A. Roguska, Fundacja na Rzecz Dzieci i Młodzieży „Szansa”, Siedlce 2013. 
cych treści. Pozaszkolne doświadczenia audiowizualne uczniów, jak pisze Lechosław Gawrecki, sprzyjały rozwojowi zasobów językowych uczniów, rozszerzeniu wiedzy na temat różnych zjawisk, a także wpływały na rozwój wyobraźni twórczej oraz odtwórczej.
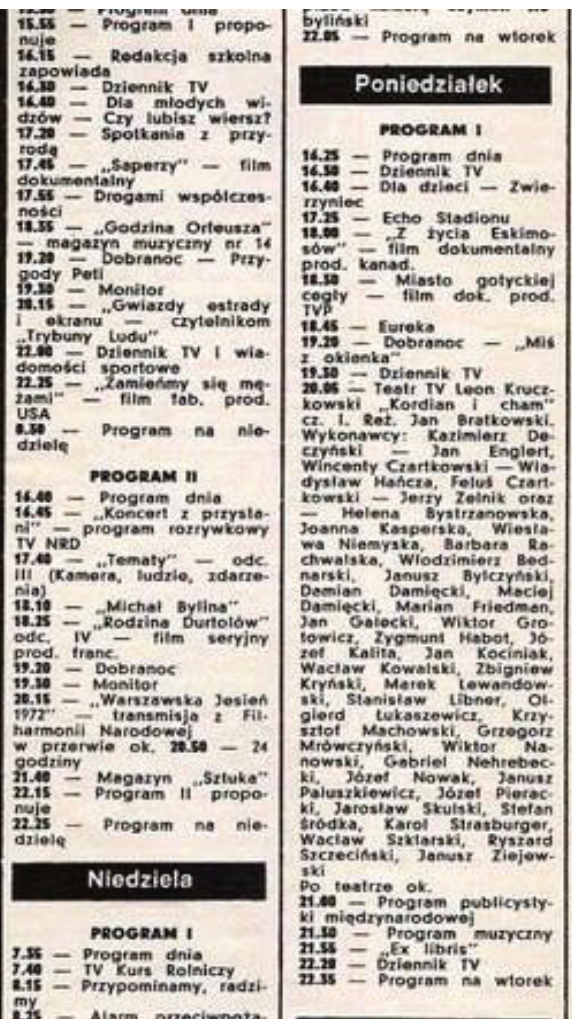
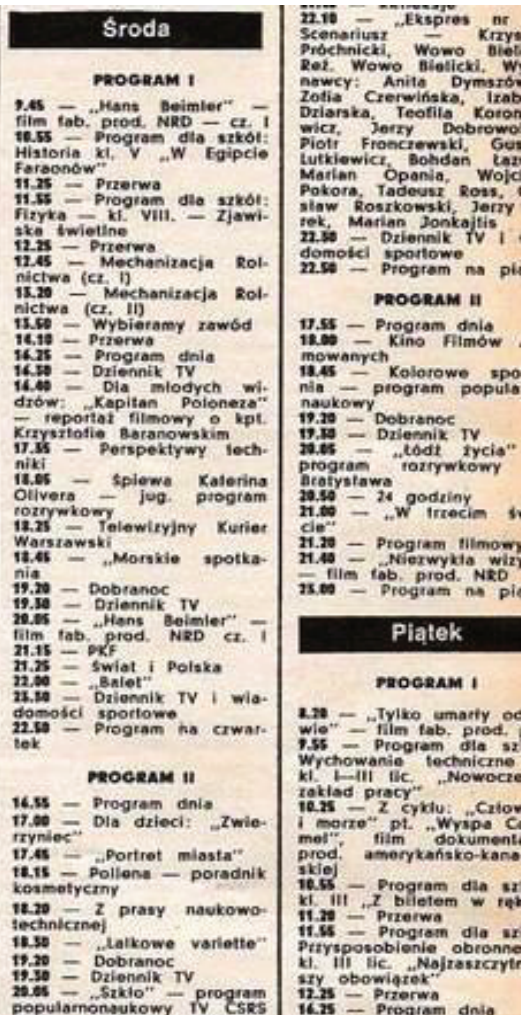

Rys. 1. Fragment programu telewizyjnego z lat 80. dwudziestego wieku, opublikowane przez użytkownika Sebastian

Źródło: Strona internetowa Retro Pewex: http:// retro.pewex.pl/475523 [dostęp: 6.06.2017].

${ }^{7}$ L. Gawrecki, Nauczyciel a pozaszkolne doświadczenia ucznia, [w:] Dokąd zmierza technologia kształcenia, red. W. Strykowski, W. Skrzydlewski, Zakład Technologii Kształcenia Instytutu Pedagogiki Uniwersytetu im. Adama Mickiewicza w Poznaniu, Poznań 1993. 
Analizując rolę komputerów w tamtych czasach, trzeba pokreślić, że dopiero zaczynały pojawiać się $\mathrm{w}$ szkołach i w gospodarstwach domowych. Ich możliwości znacznie różniły się od możliwości urządzeń, z którymi pracujemy współcześnie. O dostępie do internetu nie było nawet mowy. Jak wynika $\mathrm{z}$ badania przeprowadzonego w terminie marzec 1986 r. - luty 1987 r. przez miesięcznik "Komputer”, najpopularniejszymi komputerami w ówczesnych gospodarstwach domowych były ex aequo ZX Spectrum (38\%) oraz Atari XL/XE (38\%). Kolejne miejsca zajmowały komputery: Comodore $(13 \%)$ oraz Amstrad (4\%). Osoby, które nie miały komputera, a również wzięły udział $\mathrm{w}$ badaniu, deklarowały, że chcą kupić następujące modele: Atari XL/XE (34\%), Amstrad CPC (15\%), PC (14\%), ZX Spectrum (13\%), Commodore (12\%), Atari ST (7\%), Amiga (1\%). W badaniach wzięło udział 3108 osób8.

Wraz z pojawieniem się komputerów w szkołach podjęto próby wprowadzania edukacji informatycznej, choć było to trudne z kilku powodów. Pierwszym z nich była liczba dostępnych komputerów. Analizując wywiad opublikowany w periodyku "Mikroklan" można zauważyć, że szkoły były raczej minimalnie wyposażone w sprzęt komputerowy. Jedna ze szkół ze szkół miała ZX Spectrum $16 \mathrm{~Kb}, \mathrm{w}$ innej dostępne były trzy komputery ZX Spectrum Plus, w jeszcze innej (aż siedem). Jak podkreślają rozmówcy ${ }^{9}$, komputery pochodziły głównie $\mathrm{z}$ darów. Nauczyciele, którzy brali udział w tym wywiadzie, jednogłośnie podkreślali potrzebę wprowadzenia komputerów do szkół i przygotowania młodzieży do życia w cywilizacji informatycznej. Drugim problemem wskazywanym przez nauczycieli w tym wywiadzie, były braki kadrowe - nie było chętnych nauczycieli do pracy na stanowisku nauczyciela informatyki, nie było osób z odpowiednim ku temu wykształceniem ${ }^{10}$. Sam

8 Więcej informacji na stronie: http:/ /retrokomputer.pl/jakie-komputery-mie lismy-w-domach-w-1986-roku-i18547.html [dostęp: 6.06.2018].

${ }_{9}^{9}$ Nauczyciele: Jerzy Kunicki, Henryk Daniszewski, Tadeusz Kuran oraz Krzysztof Kontek w imieniu Mikroklanu.

${ }^{10}$ K. Kontek, Oczami nauczycieli, „Mikroklan” Zeszyt 2/1986, http://idn.org.pl/ users/lesz/legend/archiw1.html [6.06.2017]. 
program edukacji informatycznej, nad którym pracowały ówczesne władze, miał być gotowy najpóźniej w październiku 1985 r., przygotowania tego projektu jednak się wydłużyły11.

W literaturze przedmiotu z tamtych czasów wskazywano, że komputer $w$ procesie kształcenia może spełniać trzy funkcje, tj. może być korepetytorem i oceniać oraz kontrolować aktywność ucznia, partnerem, pozwalając na programowanie konkretnych programów, oraz pomocnikiem przy wykonywaniu pewnych czynności. Przykładowe programy $\mathrm{z}$ tamtych czasów służące edukacji to HyperTalk oraz LogoWriter. Powszechność użytkowania komputerów nie była jednak duża, a zajęcia z nimi miały osoby, które specjalizowały się raczej w przedmiotach ścisłych. Dla osób z klas humanistycznych czy osób $\mathrm{z}$ różnorodnymi niepełnosprawnościami dostęp do komputerów był ograniczony ${ }^{12}$.

Podsumowując analizę dzieciństwa medialnego rodziców współczesnych nastolatków, należy zwrócić uwagę, że wychowywali się oni $\mathrm{w}$ przestrzeni, w której dostęp do mediów tradycyjnych był coraz swobodniejszy. Po ruchach społecznych, które miały miejsce na początku lat 80. XX w., dostęp do mediów przestał być aż tak kontrolowany. Media również zaczęły się rozwijać. Ówczesna młodzież miała więc możliwość obcowania z różnymi ich formami. Nie tylko prasą czy radiem, ale również z telewizją. W szkole $\mathrm{w}$ latach 80. komputery pojawiały się stopniowo. I mimo tego, że z pewnością nie każdy z rodziców miał do nich dostęp, nie są to dla nich urządzenia obce. Rokrocznie komputerów przybywało, znajdywały zastosowanie nie tylko $\mathrm{w}$ dziedzinach ścisłych, bazujących na technice i przemyśle, ale również zaczęły być stosowane $\mathrm{w}$ dziedzinach humanistycznych. Rodzice mieli szansę na bliższy kontakt z nimi. Warto również dodać, że rodzice współczesnych nastolatków są

11 D. Majewska, W. Majewski, Zamiast programu, „Komputer”, kwiecień 1986, http://idn.org.pl/users/lesz/legend/archiw1.html\#dwa [dostęp: 6.06.2018].

12 Brelińska, K. Wczoraj, dziś i jutro komputerów w nauczaniu, [w:] Dokąd zmierza technologia kształcenia, red. W. Strykowski, W. Skrzydlewski, Poznań: Zakład Technologii Kształcenia Instytutu Pedagogiki Uniwersytetu im. Adama Mickiewicza w Poznaniu, Poznań 1993. 
świadkami tego, w jaki sposób zmieniał się dostęp do mediów oraz ich formy. To właśnie oni wiedzą, jak wyglądał świat, praca i życie bez internetu. Widzą również to, co dzieje się teraz, kiedy internet tak mocno wciąga użytkowników w swoje przestrzenie. Taki stan rzeczy niewątpliwie miał wpływ na to, jakimi kompetencjami medialnymi cechują się te osoby współcześnie.

\section{Cel i metody badań}

Celem badań było określenie, w jakim zakresie nowe media wspierają rodzica we współczesnej szkole. Badania prowadzono w pięciu obszarach, tj. nowomedialne zarządzanie szkołą, budowanie relacji między szkołą a rodzicami, nowomedialna (auto)promocja szkoły, nowomedialne wspomaganie procesu nauczania - uczenia się, nowomedialna aktywność uczniów. Pierwszy ze wskazanych obszarów dotyczył głównie osób zarządzających szkołami, dlatego poniżej pominięto ten aspekt w wynikach

Badania przeprowadzono w 18 szkołach gimnazjalnych działających w województwie lubuskim. W badaniach wzięli udział uczniowie (386 osób), nauczyciele (271 osób), dyrektorzy (18 osób), a także rodzice (357 osób), których bezpośrednio dotyczy niniejszy artykuł. Badania prowadzone były metodą sondażu diagnostycznego w przypadku uczniów, rodziców oraz nauczycieli, jak i wywiadu częściowo skategoryzowanego w przypadku dyrektorów szkół. Procedury zostały przeprowadzone od kwietnia do czerwca 2016 r.

\section{Opis grupy badanej}

W przeprowadzonych badaniach, jak już wspomniano, wzięło udział 357 rodziców badanych gimnazjalistów. Średnia wieku osób badanych wynosi 42 lata. W badaniach wzięły udział 202 kobiety oraz 64 mężczyzn. Odpowiedzi na pytanie dotyczące wykształcenia 
udzieliły 333 osoby. 37\% osób badanych ma wykształcenie średnie, zawodowe $-21,8 \%$, wyższe magisterskie $-17,4 \%$, natomiast wyższe licencjackie $7,3 \%$. Jeśli chodzi o profesje wykonywane przez osoby badane, to $20,5 \% \mathrm{z}$ nich zajmuje się pracą usługową, $16,6 \%$ obecnie nie pracuje, a 12,7\% osób (49 ankietowanych) pracuje w przemyśle. Należy dodać, że 74 osoby nie udzieliły odpowiedzi na to pytanie, a 11 osób zaznaczyło odpowiedź Inne, więc rzeczywisty obraz pracy wykonywanej przez rodziców badanych uczniów może nieco się różnić.

Samoocena badanych rodziców $\mathrm{w}$ zakresie obsługi komputera i urządzeń z nim związanych pokazuje, że nieco ponad $40 \%$ rodziców umie na bardzo dobrym poziomie korzystać z komputera i urządzeń z nim związanych. Co więcej, 51,2\% respondentów stwierdziło, że bardzo dobrze posługuje się interetem. Jeśli chodzi o programy komputerowe, nieco ponad 75\% ankietowanych deklaruje co najmniej średni poziom znajomości obsługi programów komputerowych.

Rodzice w oczach swoich dzieci wypadają gorzej - uczniowie umiejętności posiadane przez opiekunów w zakresie obsługi komputera, programów komputerowych oraz internetu oceniają niżej. $34,4 \%$ ankietowanych gimnazjalistów ocenia umiejętności rodziców $\mathrm{w}$ zakresie korzystania $\mathrm{z}$ internetu jako bardzo dobre. W przypadku komputerów jest to nieco ponad $25 \%$ ankietowanych uczniów. Najbliższe sobie odpowiedzi można obserwować w przypadku korzystania z programów komputerowych - 28,5\% badanych uczniów ocenia umiejętności swoich rodziców w tym zakresie jako średnie.

Jak wynika z przeprowadzonych badań, 30-40\% rodziców potrzebuje pomocy od swoich dzieci w przypadku obsługi komputera, programów komputerowych czy internetu kilka razy w miesiącu. Prawie 50\% respondentów wcale nie potrzebuje takiej pomocy $\mathrm{w}$ przypadku korzystania $\mathrm{z}$ internetu.

Uczniowie deklarowali, że wcale nie pomagają rodzicom $\mathrm{w}$ obsłudze komputera i urządzeń z nim związanych (26,4\% badanych) lub robią to kilka razy $\mathrm{w}$ miesiącu $(36,1 \%)$. $\mathrm{W}$ przypadku programów komputerowych $34,1 \%$ ankietowanych uczniów podało, że nie 
pomaga rodzicom nigdy, a 33,9\% robi to kilka razy w miesiącu. Jeśli chodzi o pomoc w obsłudze internetu, $41,3 \%$ badanych twierdzi, że wcale nie pomaga rodzicom $\mathrm{w}$ tym zakresie.

\section{Wybrane wyniki badań własnych}

\section{Nowomedialne budowanie relacji między szkołą a rodzicami}

Jak pokazują przeprowadzone badania, to właśnie rodzice byli grupą, dzięki której w wielu szkołach pojawiły się dzienniki elektroniczne. $\mathrm{Z}$ wywiadów przeprowadzonych $\mathrm{z}$ dyrektorami szkół wynika, że pod naciskiem opiekunów do większości badanych szkół wprowadzano elektroniczną dokumentację, ponieważ rodzice byli przyzwyczajeni do tej formy komunikacji od szkoły podstawowej. Ponad $1 / 4$ badanych rodziców deklaruje, że z dzienników elektronicznych korzysta codziennie (26,4\%). Odpowiedzi kilka razy $w$ miesiacu oraz kilka razy w tygodniu udzieliło odpowiednio 22,7\% oraz $22 \%$ badanych. $11,2 \%$ respondentów zadeklarowało, że nigdy nie korzysta z dziennika elektronicznego, mimo że takie narzędzie jest dostępne w szkole, do której uczęszcza ich dziecko. Co jednak ciekawe, najpopularniejszym kanałem komunikacji jest jednak telefon (takiej odpowiedzi udzieliło $40 \%$ badanych nauczycieli oraz $31 \%$ badanych rodziców). Na drugim miejscu znalazł się kontakt osobisty (22,1\% i 30,2\% odpowiedzi), natomiast na trzecim komunikacja elektroniczna poprzez dziennik elektroniczny oraz pocztę e-mail (20,7\% badanych). Co ciekawe, u rodziców ta odpowiedź znalazła się dopiero na czwartym miejscu, a wybrało ją 9,7\% osób badanych. Dwie osoby w kategorii Inne podały odpowiedź Facebook oraz Messenger (chat udostępniony przez portal społecznościowy Facebook). Uzasadniając odpowiedzi, nauczyciele podawali, że kontakt telefoniczny jest najszybszy - w razie potrzeby można skontaktować się z rodzicem i przekazać konkretne informacje. Ten sposób kontaktu sprawdza się również w komunikacji z rodzicami, którzy nie mają konta w dzienniku elektronicznym lub z niego nie 
korzystają. Dziennik elektroniczny sprawdza się raczej w przekazywaniu neutralnych informacji, takich jak dane o wyjeździe, zbiórka pieniędzy czy inne kwestie organizacyjne.

Co istotne, mimo że to rodzice chcieli wprowadzenia dzienników elektronicznych, nie korzystają oni z niego w celach komunikacyjnych. Służy im on raczej jako narzędzie nadzoru postępów oraz frekwencji swoich dzieci. Rodzice najczęściej korzystają z dziennika elektronicznego, by sprawdzić oceny dzieci (290 odpowiedzi) oraz frekwencję (119 odpowiedzi), a także by skontaktować się z nauczycielami poza sytuacją zebrania klasowego. (80 odpowiedzi). 105 osób odpowiedziało, że nie korzysta z dziennika elektronicznego, natomiast 36 osób badanych nie miało do niego dostępu (ponieważ szkoła z niego nie korzystała).

Przez rodziców - respondentów dzienniki elektroniczne, z których korzystają szkoły, są oceniane bardzo dobrze. Od $46 \%$ do $60 \%$ badanych wskazało, że bardzo podobają się im wskazane w ankiecie cechy tego narzędzia. Najwięcej ankietowanych najwyżej oceniło możliwość kontaktowania się z nauczycielami przez dziennik elektroniczny.

\section{Nowomedialna (auto)promocja szkoły}

12 spośród 18 badanych gimnazjów miało profil na tym portalu społecznościowym, natomiast jedno z nich prowadzi regularny kanał na YouTube. Prawie $60 \%$ badanych nie ma zdania na ten temat. $22 \%$ udzieliło odpowiedzi Tak, natomiast $18,1 \%$ Nie.

Badani rodzice zostali zapytani również o zainteresowanie śledzeniem kanału szkoły na stronach umożliwiających transmisję i publikację materiałów audiowizualnych. Także w tym przypadku znaczna większość badanych nie miała zdania na ten temat (69\%). Niecałe $11 \%$ było za, natomiast $20 \%$ respondentów udzieliło odpowiedzi przeciwnej.

Respondenci niestety nie uzasadnili swoich odpowiedzi na pytania zamknięte, nie można więc wskazać żadnych argumentów za (nie)posiadaniem kont na portalach społecznościowych. 
Jeśli chodzi o ocenę stron internetowych prowadzonych przez szkoły, badani rodzice oceniają je raczej pozytywnie. Ponad $60 \%$ respondentów deklarowało, że podoba im się ona pod względem wyglądu, intuicyjność, dostępność na innych urządzeniach, a także pod względem zawartych na niej treści.

Z przeprowadzonych badań wynika, że rodzice chcą śledzić informacje ze szkół swoich dzieci, jednak nie są przekonani co to tego, by treści te były publikowane w mediach społecznościowych.

\section{Nowomedialne wspomaganie procesu nauczania - uczenia się oraz nowomedialna aktywność uczniów}

Analiza zgromadzonych danych pokazała, że w tym przypadku rodzice i uczniowie mają podobne zdanie. Rodzice są przekonani o tym, że ich dzieci, przygotowując się do zajęć szkolnych, korzystają z encyklopedii wirtualnych $(22,1 \%$ z zaledwie 113 uzyskanych odpowiedzi) oraz tłumaczy wirtualnych $(16,8 \%$ odpowiedzi). Nieco ponad $20 \%$ odpowiedzi udzielonych przez rodziców sugeruje, że nie wiedzą oni, przy pomocy jakich narzędzi ich dzieci przygotowują się do zajęć szkolnych. Jest to dość niepokojące, szczególni, że w internecie, oprócz wiedzy, znajdziemy wiele informacji fałszywych, które mogą wprowadzić młodego człowieka w błąd. Problem stanowi również zjawisko cyberprzemocy, które może przybierać różne formy. Jeśli rodzice nie będą wiedzieli, z jakich źródeł korzystają uczniowie i na jakich stronach internetowych się poruszają, może to stanowić bezpośrednie zagrożenie nie tylko dla młodzieży korzystającej z internetu, ale również dla ich najbliższego otoczenia.

Jak pokazują badania, młodzież przygotowując się do zajęć szkolnych, korzysta głównie z Wikipedii (70\% badanych uczniów), aż 40\% robi to codziennie. Wśród badanych gimnazjalistów równie popularny jest Ttumacz Google, z którego co najmniej kilka razy w miesiącu korzysta prawie $70 \%$ badanych. W przypadku innych narzędzi jest jednak nieco gorzej - 74\% badanych uczniów w ogóle 
nie korzysta z wirtualnych dysków, przygotowując się do zajęć. Co więcej, 75\% uczniów nie korzysta również z wirtualnych dokumentów - w pytaniach otwartych, dotyczących celu korzystania ze wskazanego narzędzia, kilkakrotnie pojawiły się odpowiedzi "a co to takiego”, „nie znam czegoś takiego”. Badani, którzy znają to narzędzie, deklarują, że korzystają z niego w czasie lekcji informatyki lub by przygotować konkretne materiały zadane przez nauczyciela. Uczniowie nie także z darmowych zasobów dostępnych w wirtualnych bibliotekach i wideotekach. Robi to zaledwie 30\%. Popularnym narzędziem są portale z opracowaniami lektur - korzysta $z$ nich ponad $60 \%$ badanych.

W czasie wolnym $69,2 \%$ badanych uczniów korzysta $\mathrm{z}$ internetu codziennie, tylko 10,2\% respondentów nie robi tego wcale. Popularne wśród badanej młodzieży są strony z rozrywką online, jak np. YouTube, CDA.pl, zalukaj.com. 61,7\% respondentów spędza na nich codziennie swój wolny czas. Z odpowiedzi ankietowanych wynika również, że w wolnych chwilach nie korzystają oni wcale z encyklopedii internetowych $(42,8 \%)$, wirtualnych dysków $(73,3 \%)$, bibliotek i wideotek online $(77,4 \%)$ oraz z portali z opracowaniami lektur czy rozwiązaniami zadań (59,5\%). Wiarygodne źródła informacji, takie jak wideoteki, encyklopedie internetowe oraz e-biblioteki, nie znalazły się w kręgu zainteresowań badanej młodzieży.

\section{Wnioski}

$\mathrm{Z}$ analizy literatury przedmiotu, przytoczonych oraz przeprowadzonych wyników badań wynika, że rodzice współczesnej młodzieży to osoby dla których świat internetu oraz nowomedialnych narzędzi nie jest światem obcym. Co prawda współcześni rodzice nastolatków czasem potrzebują pomocy w obsłudze konkretnych urządzeń, programów czy aplikacji, jednak podstawowe czynności, takie jak sprawdzenie poczty, prowadzenie swojego konta na portalu społecznościowym czy dokonywanie zakupów, nie stanowią dla 
nich większych problemów. Poważniejszy problemem jest jednak niewiedza rodziców dotycząca tego, co ich dzieci robią w sieci, z jakich stron korzystają, jakie aktywności podejmują. Niewiedza ta może prowadzić do wielu problemów nie tylko wychowawczych, ale i rozwojowych. Młodzież przecież znajduje się w bardzo newralgicznym momencie swojego życia i jest podatna na różne wpływy - łatwo przekonać ją do fałszywych informacji. Oczywiście sytuacja ta będzie się oczywiście zmieniać, bo osoby z coraz bardziej medialnego świata stają się rodzicami i mają większą wiedzę na temat nowomedialnych możliwości i zagrożeń. Póki jednak świadomość naszego społeczeństwa dotycząca korzystania z nowych mediów jest niewielka, należy prowadzić szeroką edukację uczniów i rodziców w tym zakresie.

\section{Bibliografia}

Brelińska K., Wczoraj, dziś i jutro komputerów w nauczaniu, [w:] Dokąd zmierza technologia kształcenia, red. W. Strykowski, W. Skrzydlewski, Zakład Technologii Kształcenia Instytutu Pedagogiki Uniwersytetu im. Adama Mickiewicza w Poznaniu, Poznań.

Gawrecki L., Nauczyciel a pozaszkolne doświadczenia ucznia, [w:] Dokąd zmierza technologia ksztatcenia, red. W. Strykowski, W. Skrzydlewski, Zakład Technologii Kształcenia Instytutu Pedagogiki Uniwersytetu im. Adama Mickiewicza w Poznaniu, Poznań 1993.

GUS, Społeczeństwo informacyjne w Polsce 2012-2016, https://stat.gov.pl/files/ gfx/portalinformacyjny/pl/defaultaktualnosci/5497/1/10/1/spoleczenstwo_ informacyjne_w_polsce_2012-2016.pdf [dostęp: 10.08.2018].

Kontek K., Oczami nauczycieli. Mikroklan. Zeszyt 2/1986. Pobrano z: http://idn.org.pl/ users/lesz/legend/archiw1.html [dostęp: 6.06.2017].

Korulska E., Stokowska A., Historia radia. Pobrano z: http:/ /www.ceo.org.pl/sites/ default/files/news-files/historia_radia_1.pdf [dostęp: 7.06.2017].

Majewska D., Majewski W. Zamiast programu. „Komputer” kwiecień 1986. Pobrano z: http://idn.org.pl/users/lesz/legend/archiw1.html\#dwa [dostęp: 6.06.2017].

Olejniczak-Szukała W., Obraz polskiej młodzieży lat osiemdziesiątych w świetle prasy młodzieżowej. Praca doktorska przygotowana pod kierunkiem prof. UAM dr hab. Doroty Skotarczak. Poznań: Wydział Historyczny. Pobrano z: https://repozyto rium.amu.edu.pl/bitstream/10593/4490/1/doktorat2.pdf [dostęp: 6.06.2017]. 
Sosnowska J., Polskie telewizyjne programy edukacyjne dla dzieci i młodzieży - zarys historyczny, [w:] Media w edukacji. Wymiar kulturowy i aksjologiczny, red. A. Roguska, Fundacja na Rzecz Dzieci i Młodzieży „Szansa”, Siedlce 2013.

TNS na zlecenie Orange Polska, Bezpieczeństwo dzieci w internecie. Raport $z$ badań jakościowych i ilościowych, https://panoptykon.org/files/bezpieczenstwo_dzieci_ w_internecie_2013.pdf [dostęp: 10.08.2018]. 